\title{
JURNAL ILMIAH \\ PREDIKSI KEJADIAN PENYAKIT TUBERKULOSIS PARU BERDASARKAN JENIS KELAMIN
}

\author{
Sri Andayani \\ Program Studi Keperawatan, Universitas Muhammadiyah Ponorogo \\ Andayani_86@yahoo.com
}

\begin{abstract}
ABSTRAK
Tuberkulosis (TBC) menjadi kasus yang selalu meningkat setiap tahunnya. Penilaian kemajuan dan keberhasilan penanggulangan penyakit Tuberkulosis paru di Kabupaten Ponorogo menggunakan indikator angka penjaringan suspek dengan promosi kesehatan khususnya TB paru. Tujuan penelitian ini untuk menganalisa prediksi kejadian penyakit Tuberkulosis Paru Berdasarkan jenis kelamin di Kabupaten Ponorogo Tahun 2016 sampai 2020. Penelitian ini merupakan studi deskriptif kuantitatif menggunakan desain cross sectional dengan pendekatan analisis time series metode trend. Populasi dan sampel dalam penelitian ini adalah seluruh data kasus TB Paru BTA Positif yang didalamnya jenis kelamin penderita selama tahun 2011-2015 di Kabupaten Ponorogo. Hasil Penelitian Distribusi kasus TB Paru BTA Positif pada periode tahun 2011-2015 cenderung meningkat dengan jumlah kasus masing-masing 276, 392, 378, 293 dan 334 kasus. Setelah diprediksikan, kasus TB Paru pada tahun 2016-2020 akan menurun dengan kasus masing-masing sebesar 299, 348, 366, 352, dan 306. Berdasarkan hasil analisis time series dengan metode trend berdasarkan jenis kelamin di Kabupaten Ponorogo pada tahun 20162020, diprediksikan bahwa kasus TB Paru akan terus meningkat dan diperkirakan pada tahun 2018 jumlah kasus tertinggi terdapat pada jenis kelamin laki-laki dengan jumlah 222 kasus, dan pada jenis kelamin perempuan sebesar 141 kasus. Simpulan, terjadi peningkatan kasus tuberculosis paru pada jenis kelamin laki-laki ditahun 2018.
\end{abstract}

Kata Kunci: Prediksi Kejadian, TBC, Jenis Kelamin

\begin{abstract}
Tuberculosis (TBC) is a case that is always increasing every year. Assessment of progress and success of pulmonary tuberculosis control in Ponorogo Regency uses indicators of suspicion screening numbers with health promotion, especially pulmonary TB. The purpose of this study was to analyze the prediction of the incidence of pulmonary tuberculosis based on gender in Ponorogo Regency from 2016 to 2020. This research is a quantitative descriptive study using a cross-sectional design with time series analysis approach with trend method. The population and sample in this study were all data on cases of smear positive lung tuberculosis which included the sex of the patient during 2011-2015 in Ponorogo Regency. Research Results The distribution of smear positive lung TB cases in the period 2011-2015 tended to increase with the number of cases respectively 276, 392, 378, 293 and 334 cases. After predicting, pulmonary TB cases in 2016-2020 will decline with cases of 299, 348, 366, 352, and 306 respectively.Based on the results of time series analysis with the trend method based on gender in Ponorogo Regency in 2016-2020, It is predicted that pulmonary TB cases will continue to increase and it is estimated that in 2018 the highest number of cases is male with 222 cases, and female sex with 141 cases. In conclusion, there has been an increase in cases of pulmonary tuberculosis in men in 2018.
\end{abstract}


Keywords: Incidence Prediction, TB, Gender

\section{PENDAHULUAN}

Tuberkulosis (TBC) merupakan penyakit infeksi menular yang disebabkan oleh Mycobacterium Tuberculosis. Tuberkulosis (TB) disebabkan oleh mikroorganisme kompleks Mycobacterium tuberculosis. Kompleks ini mencakup Mycobacterium Tuberculosis, yaitu agen penyebab penyakit mikobakterial yang paling penting dan paling sering ditemukan pada manusia.

Kasus tuberkulosis paru dengan BTA positif di Kabupaten Ponorogo semakin tahun semakin meningkat. Hal tersebut dapat dilihat pada data temuan kasus tuberkulosis paru BTA positif pada tahun 2011 sampai dengan tahun 2015. Pada tahun 2011 didapatkan data penderita tuberkulosis sebesar 276 kasus dari 859.302 penduduk, tahun 2012 didapatkan 392 kasus dari 861.806 penduduk, pada tahun 2013 didapatkan 378 kasus dari 863.890 penduduk, pada tahun 2014 ditemukan 293 kasus dari 865.809 penduduk dan ditemukan 334 kasus tuberkulosis paru BTA positif dari 867.393 penduduk (Dinkes Ponorogo, 2016).

Kasus tuberkulosis paru sematamata tidak hanya disebabkan oleh bakteri akan tetapi ada beberapa faktor lain yang sangat berpengaruh terhadap tuberkulosis paru. Faktor tersebut bisa dari diri pasien sendiri (usia, jenis kelamin, penyakit penyerta, status gizi/nutrisi, imunisasi, kebiasaan merokok) dan faktor eksternal (lingkungan, sosial ekonomi) (Atik, 2013).

Di Kabupaten Ponorogo sebagian besar penderita Tuberkulosis paru diderita oleh laki-laki dan masih berusia produktif. WHO (2003) menuliskan bahwa hampir $90 \%$ penderita TB paru menyerang hampir semua golongan umur khususnya ditemukan pada usia produktif (15-50 tahun). Usia produktif merupakan usia dimana seseorang berada pada tahap untuk bekerja atau menghasilkan sesuatu baik untuk diri sendiri maupun orang lain.

Program pemerintah yang sudah dilaksanakan harus selalu dievaluasi untuk mengetahui sejauh mana keberhasilan dari program-program itu. Prediksi kejadian Tuberkulosis paru juga diperlukam untuk beberapa tahun yang akan datang. Pemerintah dan pelayanan kesehatan bisa mempersiapan program baru yang lebih baik lagi (Infodatin TB, 2012).

Pelaksanaan prediksi kejadian tuberkulosis tersebut diperlukan data yang dipergunakan sebagai acuan dalam melakukan prediksi. Data yang dimaksud adalah data berkala (Time series) yakni data yang didapatkan menurut beberapa waktu (hari, minggu, bulan, tahun) dan secara berurutan untuk menggambarkan suatu kegiatan.

Penelitian ini sejalan dengan penelitian yang dilakukan oleh Rukmini \& Chatarina (2016) yang meneliti Faktor-faktor yang berpengaruh terhadap kejadian Tuberkulosis paru dewasa di Indonesia (analisa data riset kesehatan dasar tahun 2010) dengan hasil Analisis multivariat menunjukkan bahwa faktor resiko yang mempengaruhi kejadian TB paru dewasa di Indonesia adalah Umur $(\mathrm{OR}=0,473)$, jenis kelamin $(\mathrm{OR}=1,613)$, energi penerangan $(\mathrm{OR}=1,804)$, status gizi $(\mathrm{OR}=2,101)$ dan kontak serumah dengan pasien $\mathrm{TB}$ paru $(\mathrm{OR}=4,355)$. Persamaannya menggunakan observasi analitik data sekunder, dengan persamaannya membahas tentang jenis kelamin sebagai factor resiko pada penderita Tuberkulosis Paru.

Berdasarkan uraian diatas maka penulis tertarik untuk meneliti tentang prediksi kejadian penyakit Tuberkulosis Paru berdasarkan jenis kelamin Kabupaten Ponorogo. Tujuan dari penelitian ini adalah untuk menganalisa 
prediksi kejadian penyakit Tuberkulosis Paru Berdasarkan jenis kelamin.

\section{METODE PENELITIAN}

Penelitian ini merupakan penelitian deskriptif kuantitatif dengan desain cross sectional dengan menggunakan pendekatan analisis time series. Populasi pada penelitian ini adalah semua rekam medis pasien Tuberkulosis paru yang tercatat berdasarkan data sekunder rekam medik dan informasi dari seluruh puskesmas yang ada dikabupaten
Ponorogo dan Dinas Kesehatan Kabupaten Ponorogo mulai bulan Januari 2011 sampai Desember 2015 sebanyak 1673 data rekam medik pasien tuberkulosis paru dengan menggunakan teknik total sampling.

\section{HASIL PENELITIAN}

Hasil Prevalensi Kejadian TB Paru Berdasarkan Jenis Kelamin di Kabupaten Ponorogo Tahun 2011-2015 dapat dilihat pada tabel berikut ini;

Tabel 1.

Hasil Prevalensi Kejadian TB Paru Berdasarkan Jenis Kelamin di Kabupaten Ponorogo Tahun 2011-2015

\begin{tabular}{lccccc}
\hline \multicolumn{1}{c}{ Karakteristik Jenis Kelamin } & $\mathbf{2 0 1 1}$ & $\mathbf{2 0 1 2}$ & $\mathbf{2 0 1 3}$ & $\mathbf{2 0 1 4}$ & $\mathbf{2 0 1 5}$ \\
\hline Laki-laki & 166 & 233 & 227 & 196 & 210 \\
Perempua & 110 & 159 & 151 & 97 & 124 \\
\hline Jumlah & 276 & 392 & 378 & 293 & 334 \\
\hline
\end{tabular}

Sumber : Data Sekunder 2016

Data kejadian Tuberkulosis paru berdasarkan jenis kelamin pada tahun 2011-2015 semua kasus terbanyak pada jenis kelamin laki-laki yakni 166 kasus (60,1\%), 233 kasus $(59,4 \%), 227$ kasus (60\%), 196 kasus (66,9\%), dan 210 kasus (62,9\%). Kejadian Tuberkulosis paru berdasarkan penyakit penyerta didapatkan data lebih dari $50 \%$ untuk setiap tahunnya. Hasil R Square Terhadap Pemilihan Analisis Metode Trend dapat dilihat pada tabel berikut ini.

Tabel 2.

Hasil R Square Terhadap Pemilihan Analisis Metode Trend Terhadap Prevalensi Kejadian TB Paru Berdasarkan Jenis Kelamin di Kabupaten Ponorogo Tahun 2011-2015

\begin{tabular}{lcccc}
\hline \multicolumn{1}{c}{ Karakteristik } & \multicolumn{4}{c}{ Hasil $\boldsymbol{R}$ Square } \\
\cline { 2 - 5 } \multicolumn{1}{c}{ Status Jenis Kelamin } & Linier & Quadratic & Exponential & Pemilihan \\
\hline Laki-laki & 0,090 & 0,515 & 0,120 & Quadratic \\
Perempuan & 0,041 & 0,249 & 0,037 & Quadratic \\
\hline Sumber:
\end{tabular}

Tabel 3.

Distribusi hasil Prediksi Kejadian TB Paru Tahun 2016-2020 Berdasarkan Kelompok Jenis Kelamin Tahun 2011- 2015 di Kabupaten Ponorogo

\begin{tabular}{ccc}
\hline \multirow{2}{*}{ Tahun } & \multicolumn{2}{c}{$\begin{array}{c}\text { Hasil Prediksi TB Paru Berdasarkan Jenis Kelamin di Kabupaten } \\
\text { Ponorogo tahun 2016-2020 }\end{array}$} \\
\cline { 2 - 3 } & Laki-Laki & Perempuan \\
\hline 2016 & 166 & 110 \\
2017 & 233 & 159 \\
2018 & 227 & 151 \\
2019 & 196 & 97 \\
2020 & 210 & 124 \\
\hline
\end{tabular}

Sumber : Data Sekunder 2016 
Berdasarkan tabel 2 diatas menunjukkan hasil bahwa pemilihan analisis metode trend yang paling cocok untuk dipergunakan adalah model quadratic, karena hasil prosentase $R$ Square yang paling besar ada pada model quadratic.

Tabel 3 menunjukkan hasil analisis time series dengan metode trend, untuk menghitung prediksi kasus TB Paru pada kelompok jenis kelamin lakilaki dan perempuan menggunakan persamaan model trend quadratic. Pada kelompok laki-laki diprediksikan angka kasus TB Paru mencapai titik tertinggi pada tahun 2018, sedangkan di tahun 2020 menurun.

Hasil prediksi kejadian TB Paru berdasarkan kelompok laki-laki, dimana pada tahun 2016 sebesar 117 kasus, tahun 2017 sebesar 211 kasus, tahun 2018 sebesar 222 kasus, tahun 2019 sebesar 220 kasus dan tahun 2020 sebesar 198 kasus. Sedangkan pada kelompok perempuan diprediksikan angka kasus TB Paru di awal dan pertengahan tahun akan meningkat, sedangkan di akhir tahun akan menurun. Hasil prediksi kejadian TB Paru berdasarkan kelompok perempuan, dimana pada tahun 2016 sebesar 122 kasus, tahun 2017 sebesar 138 kasus, tahun 2018 sebesar 141 kasus, tahun 2019 sebesar 131 kasus dan tahun 2020 sebesar 108 kasus.

\section{PEMBAHASAN}

Identifikasi kejadian TB Paru pada variabel jenis kelamin berperan dalam kejadian TB paru, dimana risiko untuk terkena TB paru paling banyak terdapat pada jenis kelamin laki-laki sebanyak 1034 penderita $(61,8 \%)$, sedangkan jenis kelamin perempuan mempunyai resiko terjadi TB paru yang sedikit dibandingkan dengan laki-laki, yaitu sebanyak 641 penderita $(38,2 \%)$. Beberapa penelitian menyatakan bahwa penyakit Tuberkulosis paru sebagian besar diderita oleh jenis kelamin laki-laki.
Penelitian yang dilakukan oleh Yunianti (2014) menujukkan hasil bahwa jumlah penderita laki-laki lebih tinggi dari perempuan, yaitu sebesar $54 \%$. Hal ini sesuai dengan hasil penelitian tentang tampilan kelainan radiologik pada orang dewasa yang menyatakan bahwa lakilaki mempunyai kecenderunganlebih rentan terhadap faktor risiko TB paru. Hal tersebut dimungkinkan karena lakilaki lebih banyak melakukan aktifitas sehingga lebih sering terpajan oleh penyebab penyakit ini. Hasil dari penelitian Redvord (2013) menyatakan bahwa kasus BTA+ pada penyakit Tuberkulosis paru menurut jenis kelamin, bahwa laki-laki lebih tinggi dari pada perempuan yaitu hampir 1,5 kali dibanding pada perempuan.

Ada penelitian yang menyatakan bahwa penemuan tuberkulosis paru banyak diderita oleh jenis kelamin perempuan. Penelitian tersebut dilakukan oleh Dotulong (2015) dalam penelitiannya menemukan responden terbanyak memiliki jenis kelamin perempuan sebanyak 58 responden $(59,8 \%)$ dan jenis kelamin laki-laki sebanyak 39 responden $(40,2 \%)$.

$$
\text { Menurut Margareth }
$$

banyaknya jumlah kejadian TB paru yang terjadi pada laki-laki disebabkan karena laki-laki memiliki mobilitas yang tinggi dari pada perempuan, sehingga kemungkinan untuk terpapar lebih besar, selain itu kebiasaan seperti merokok dan mengkonsumsi alkohol yang dapat menurunkan sistem pertahanan tubuh, sehingga wajar bila sebagai perokok dan peminum alkohol yang sering disebut sebagai agen dari penyakit TB Paru. Laki-laki lebih berat beban kerjanya, kurang istirahat, gaya hidup yang tidak sehat.

Perbedaan juga dapat dipengaruhi oleh sistem biologis, peran gender di lingkungan sosial masyarakat, risiko terpapar dan akses ke fasilitas pelayan kesehatan memiliki hubungan dengan terjadinya penyakit TB Paru (Hermawan 
dkk, 2015). Hal tersebut dapat berdampak pada kebiasaan penderita laki-laki yang harus sadar akan bahaya penularan penyakit TB paru, sehingga kebiasaan merokok maupun alkoholik dapat dikurangi ataupun dihindari selama pengobatan nantinya dan hentikan kebiasaan buruk yang dapat mengganggung kesehatan tubuh, terutama sistem respirasi (pernasafan). Perbedaan insiden penyakit menurut jenis kelamin dapat timbul, karena bentuk anatomis, bentuk fisiologis dan sistem hormonal yang berbeda.

Hasil penelitian ini mempunyai prediksi kejadian TB Paru berdasarkan jenis kelamin penderita terbanyak adalah laki-laki yang diprediksikan terjadi penurunan kejadian TB paru di awal tahun 2017, kemudian meningkat kejadian TB paru di pertengahan tahun setelahnya, sedangkan di akhir tahun 2020 terjadi penurunan terhadap kejadian TB paru, namum masih dalam jumlah kecil dari pada tahun sebelumnmya. Sedangkan jenis kelamin perempuan yang mempunyai prediksi kejadian TB paru terkecil. Prediksi tahun 2018 jumlah kasus tertinggi terdapat pada jenis kelamin laki-laki dengan jumlah 222 kasus, dan pada jenis kelamin perempuan sebesar 141 kasus.

Hal tersebut didukung penelitian yang dilakukan oleh Indah Mahfuzhah (2014) di kota Pontianak yang menyatakan bahwa secara statistik ada hubungan antara jenis kelamin laki-laki dengan penderita tuberkulosis paru. Sedangkan hasil penelitian ini berbeda dengan penelitian yang dilakukan oleh Siti Aminah pada tahun 2012 di kota Bandar Lampung yang menyatakan jenis kelamin tidak mempunyai hubungan dengan kejadian TB paru.

Meskipun hasil di atas menunjukkan perbedaan yang cukup besar, namun dapat dikatakan bahwa perempuan lebih rentan untuk terkena penyakit TB Paru. Hal tersebut sejalan berdasarkan dengan data Global
Tuberculosis Report dalam WHO 2014 bahwa TB paru semakin banyak terjadi pada kaum muda, dimana lebih banyak terjadi pada masyarakat yang produktif secara ekonomi, terutama pada jenis kelamin perempuan yang berusia 15-24 tahun.

\section{KESIMPULAN}

Distribusi penderita TB Paru berdasarkan jenis kelamin di Kabupaten Ponorogo pada tahun 2010 - 2015 selalu meningkat setiap tahunnya. Pada masa prediksi yaitu pada tahun 2016 - 2020, diprediksikan bahwa kasus TB Paru akan terus meningkat dan diperkirakan pada tahun 2018 jumlah kasus tertinggi terdapat pada jenis kelamin laki-laki dengan jumlah 222 kasus, dan pada jenis kelamin perempuan sebesar 141 kasus.

\section{DAFTAR PUSTAKA}

Atik, P (2013). Faktor-faktor yang berhubungan dengan kejadian Tuberkulosis paru pada usia dewasa (study kasus dibalai pencegahan dan pengobatan penyakit paru) (http://illeprints.undip.ac.id/5283)

Departemen Dalam Negeri (2016). Jumlah Jumlah Penduduk Kabupaten Ponorogo Tahun 2010 - 2016. Di akses pada tanggal 20 Desember 2016, http://www.depdagri.go.id/pages/profil -daerah/kabupaten/id/35/name/jawatimur/detail/3502/ponorogo.

Dharma., \& Kelana, K. (2011). Metodologi Penelitian Keperawatan (Pedoman Melaksanakan dan Menerapkan Hasil Penelitian). Jakarta ; CV. Trans Info Media.

Dotulong., J, dkk (2015). Hubungan faktor resiko umur, jenis kelamin, dan kepadatan hunian dengan kejadian penyakit Tuberkulosis Paru di Desa Wori Kecamatan Wori. Fakultas Kedokteran Universitas Samratulangi Manado.

Erika., Ani., \& Meidiana (2016). Faktor yang Mempengaruhi Efikasi Diri pada Pasien TB Paru. Journal of Nursing 
and Health (JNH), Edisi 2, No 1, Hal 242-282

Hermawan., Ambo., \& Lymbran (2014). Prediksi Kejadian Penyakit TB Paru BTA Positif Di Kota Kendari Tahun 2016-2020. Fakultas Kesehatan Masyarakat Universitas Halu Oleo. Vol.2, No.1, Hal. 1-10, Maret. 2014

Kemenkes Republik Indonesia. (2012). Pedoman Nasional Penanggulangan Tuberkulosis. Jakarta : Direktorat Jendral Pengendalian Penyakit dan Penyehatan Lingkungan.

Mahfuznah, I (2014). Gambaran faktor risiko penderita $T B$ paru berdasarkan status gizi dan pendidikan di RSUD dokter Soedarso. Universitas Tanjungpura Pontianak.

O'Garra Redford PS., McNab FW., Bloom CI., Wilkinson RJ., \& Berry MP (2013). The immune response in tuberculosis. Annu Rev Immunol. 31: 475+527. doi: 10.1146/annurevimmunol-032712-095939 PMID: 23516984

Sarce \& Suarni (2016). Faktor yang Berhubungan dengan Kejadian $\mathrm{Tb}$ Paru Di Rsud Labuang Baji Makassar. Jurnal Ilmiah Kesehatan Diagnosis Volume 9 Nomor 2 Tahun 2016

Siti Aminah (2012). Faktor-faktor yang berpengaruh terhadap kejadian TBparu Usia diatas 14 tahun di Wilayah Kecamatan Kedaton Kota Bandar Lampung.

World Health Organization (WHO) (2014). Global Tuberculosis Report 2015. http://www.who.int/tb/publications/glo bal_report/en/. Diakses pada tanggal 17 Desember 2016.

World Health Organization (WHO) (2006). Global Tuberculosis Control -Epidemiology, Strategy, Financing. Geneva: World Health Organisation.

World Health Organization (2014). Global Tuberkulosis Control. Report 2014. (online) (Http://apps.who.int/iris/bitstream/pub lications/globalreport/10065/137094/1 19789241564809_eng.pdf?ua=1) 